\title{
On the Liquidity Effect of Monetary Policy in the CEMAC Countries: An Empirical Investigation
}

\author{
Samba Michel Cyrille \\ Shanghai University of Finance \& Economics \\ No 369 Zhong Shan Bei Yi Road, Room 80 228, International Students' Building
}

\begin{abstract}
The aim of this paper is to investigate on the effectiveness of the liquidity effect of monetary policy actions in the CEMAC region. As the conventional wisdom states, a cornerstone for the central bank to stimulate the economy is to lower interest rates by increasing the supply of narrow money. To circumvent some of the difficulties inherent to the verification of this assumption, we adopt in this study, a methodology advocated by Christiano and Eichenbaum(1991) which seems appropriate in the special case of the CEMAC countries. The results we obtain indicate that the conventional wisdom holds both on individual level and on a regional basis when the monetary aggregate measures the stance of monetary policy. Moreover, an unanticipated credit expansion causes the interest rate to decline in most of the CEMAC countries. However, both the liquidity effect and the loanable effect are offset most of the time by a price puzzle or an output puzzle. In some countries, there is also an evidence of a liquidity puzzle. On the other hand, identification assumptions based on the interest rate are unsuitable for an appropriate assessment of the liquidity effect in the region.
\end{abstract}

Keywords: Monetary Policy, Liquidity Effect, Liquidity Puzzle, Interest Rates, Granger-Causality, Loanable funds effect

\section{Introduction}

The ability of monetary policy to directly affect interest rates is central to traditional Keynesian theories of the transmission of monetary policy shocks to the real sector where incomes are formed. This phenomenon, dubbed "the liquidity effect", is also a central element in monetarist theory and recent neoclassical models (Leeper and Gordon, 1992; Guirguis, 1999). Conventional wisdom holds that unanticipated expansionary monetary policy shocks cause transient but persistent decrease in real and nominal interest rates and a persistent increase in the level of employment and output (Christiano and Eichenbaum, 1992). Meanwhile, this conventional wisdom seems to be challenged by the classical Fisher effect. According to this view, an exogenous persistent increase in money is predicted to increase expected inflation and so increase nominal interest rates. Friedman (1968) argues that, in practice, both forces operate: a persistent increase in the money supply both reduces nominal interest rates and increases expected inflation so that the real rate-nominal minus expected inflation- also falls. Leeper and Gordon (1992) state that the traditional analysis of the liquidity effect, as presented in Friedman (1968) or Cagan(1972), is firmly rooted in the comparative statics of money demand: an increase in the rate of growth in the money supply, holding output and prices constant, causes the nominal interest rate to fall. As long as prices and output do not respond "too quickly", the partial equilibrium analysis carries over to the general equilibrium. That is: After an increase in money growth, there will be a period over which the interest rate is depressed. However, expected inflation will adjust to the new growth rate of money and the long-run correlation between the interest rate and money growth is positive. For the traditional Friedman-Cagan analysis, the negative interest rate elasticity of money demand produces the liquidity effect, but ultimately the expected inflation effect dominates the liquidity effect. This prevailing wisdom about the working of monetary policy is by no means uncontroversial. Real business cycle (RBC) models built in a Cash-in-advance (CIA) framework, for instance, have the property that unexpected increases in the growth rate of money drive up nominal interest rates and inflation, while lowering output and employment (Greenwood and Huffman, 1987). In the CIA model, households immediately spend an unexpected increase in money on a fixed quantity of real goods. This increases the price level one-for-one with the increase in the money supply so that the real balances are unchanged. In addition, because money growth is serially uncorrelated, expected inflation is constant. Therefore, constant real balances and constant expected inflation imply that the money market clears at a constant nominal interest rate. If instead, monetary growth shocks are persistent, then a positive shock increases expected inflation and nominal interest rates increase. There is a Fisher effect but not the liquidity effect. Calibrated CIA models like in Greenwood and Huffman (1987), Christiano(1991), Christiano and Eichenbaum(1992), Hodrick, Kocherlakota and Lukas(1991) and Giovannini and Labadie(1991) all lead to this conclusion. Subsequent research aiming at correcting this counter-intuitive implication has been conducted by number of authors. Those works, beginning with Lucas (1990), depart from the basic CIA model to derive the superiority of the liquidity effect on the Fisher 
effect at long horizons. Lucas (1990) modifies the standard endowment economy with a simple timing assumption that households have to allocate cash between a good market and an asset market before observing the size of an open market operation. Therefore, an unexpected purchase of bonds produces an unexpectedly large amount of cash available to purchase assets, so bonds prices increase and the nominal interest rate falls. Fuerst(1992) and Christiano and Eichenbaum(1995) integrate this timing assumption into otherwise standard real business cycle models where in each period, firms have to borrow cash from financial intermediaries in order to pay their workers. After a positive monetary shock, the nominal interest rate decreases so that firms find it optimal to borrow the unexpected increase in money balances. This increases firms' labor demand and increases output (Edmond and Weill, 2005). But as it is recognized by Braun and Shioji(2002), it is remarkably difficult to formulate either sticky price or flexible price models that produce large persistent liquidity effects without appealing to quadratic adjustment costs and/or assuming labor supply elasticities that are implausible large (see e.g. Christiano, 1991; Christiano and Eichenbaum, 1992; and Christiano, Eichenbaum and Evans, 1998). Moreover, Braun and Shioji (2002) argue that the magnitude of the liquidity effect is likely to vary across time and countries and its persistence will depend on details of the economy that researchers don't have much information about.

Works by Grossman and Weiss (1983) and Alvarez, Atkeson and Kehoe (2002) also aim at supporting the conventional wisdom.

Controversies raised by the apparent weakness of liquidity effects associated with expansionary monetary policy have led to subsequent researches. As argued by Christiano and Eichenbaum(1991), analysts of monetary policy most deal with two main problems: The first one is the choice of the best measure of money and the other concerns which set of identifying assumptions to adopt to measure the exogenous component of changes in monetary policy. In fact the choices of the monetary aggregate and identifying assumptions cannot be viewed as distinct problems. For Christiano and Eichenbaum(1991), there is no reason to believe that any set of identifying assumptions will be equally appropriate across different measures of money. Usually, the choice of the monetary aggregate is coupled with the identifying assumption that unanticipated changes in monetary policy can be measured by some orthogonalized component of the innovation in money. However the use of monetary aggregates as measures of exogenous policy disturbances has raised some consistent problems. According to Srongin(1995), the first and most troublesome is that the use of standard monetary aggregates seems to be associated with the well-Known "liquidity puzzle", that is the rising rather than falling of interest rates(Note 1). Leeper and Gordon(1992) show that what relationship there is between innovations in the monetary base(as well as broader monetary aggregates) and interest rates is highly uncertain, varies across time, and usually has the opposite sign than that predicted by the liquidity hypothesis. The second problem is related to the ability of monetary aggregates to Granger-cause output in VAR specifications that either exclude interest rates or include them. In the first case, monetary aggregates do Granger-cause output, while in the second case, they no longer cause output (See Sims, 1980 and Litterman and Weiss, 1985). A third problem also documented in Sims (1980) and Litterman and Weiss (1985) is that innovations in money explain a very small proportion of the variance of output, in those VARs that include both money and interest rates. On the contrary, innovations in interest rates typically explain a very high percentage of the variance of output, indicating that innovations in policy (as measured by money) have little explanatory power. Due to the apparent inability of money based measures to better represent the actions of the monetary authority, numbers of authors (Sims, 1992 and Bernanke and Blinder, 1992 among others) have proposed to identify policy directly with innovations in interest rates. However, although this identification scheme leads to some interesting results about the liquidity effect, some conceptual and empirical problems remain unsolved. Strongin(1995) argues that, to attribute innovations in interest rates to monetary policy actions, there is a need of a clear demonstrated empirical linkage between Federal Reserve actions and interest rate movements. Another shortcoming of the identification scheme based on interest rates is that of fragile inference. As noted by Strongin(1995), the validity of such identification hinges critically on the specification's ability encompass all other significant determinants of interest rate except policy. This suggests that inferences about policy could be very sensitive to specification and omitted variable problems. Only if monetary policy far outweighs all excluded variables in terms of explaining interest rates would inferences be robust, all that is hard to argue from theory and empirical work. This said, neither the identification scheme based on monetary aggregates nor the one using interest rates seem satisfactory. Consequently, many studies (especially in the case of the United States) have proposed to use the Non-Borrowed reserves (NBR). NBR have indeed led to successful results about the liquidity effect of monetary policy (see Strongin, 1995; Guirguis, 1999; Christiano and Eichenbaum, 1991). 
After a long period of financial repression spanning from 1973 to 1990, the monetary authority in the CEMAC region came to recognize the necessity to move to a more liberalized financial system. Thus as from 1990, direct instruments were abandoned in favor of indirect instruments and the implementation of a monetary programming. The new deal of monetary policy was also followed by a vast banking reform and the launching in 1994 of the monetary market in which the central bank plays an important role. The central bank has been assigned the objective of monetary stability. It relies on a monetary programming framework to decide monetary aggregates growth and refinancing objectives which are compatible with the realization of the final objective of monetary policy. The central bank actions are based on a bank liquidity control through a refinancing policy and the imposition of reserve requirements. Thus its instruments include four director interest rates and a differentiated rate for reserve requirements. As monetary stability stands for a low level of inflation and a sufficient hedge rate of the money, the central bank is equally concerned about the evolution of money supply, the domestic credit and evolution of foreign assets. It elaborates norms for the evolution of two aggregates considered as intermediary: the credit to the economic sector and the monetary aggregate (M2). Actions on these two aggregates may help the BEAC to attain its final objectives, that is, the external hedge of the currency (article 11 of the statutes) and price stability.

The aim of the current paper is thus to assess the liquidity effect of monetary policy in the six countries forming the CEMAC (Note 2). We will be guided in this exercise by the above literature. Especially, if monetary authorities in the CEMAC area make use of a policy interest rate to stabilize the economy in the region, they also control the evolution of monetary aggregates and the level of domestic credit to the private sector. Therefore, it is useful, in the investigation of the liquidity effect in the region to see which set of policy identifications leads to the liquidity effect. Moreover, as some intermediary policy instrument, the use of domestic credit must enable us to shed light on the "loanable funds effect", the expected once-for-all drop in interest rate the increase of loanable funds shall produce, as put forward by Friedman and Schwartz(1982). Our empirical results show that the conventional wisdom holds both on individual and regional levels when the monetary aggregate stands for the policy variable. However, the liquidity effect is undermined most of the time by various types of puzzles. Another important result is that identification assumptions based on interest rates are unsuitable for the assessment of the liquidity effect in the region. Those identification schemes are the one leading to the worst results, compared to the identification schemes based on the monetary aggregate.

Finally, like actions on monetary aggregate prove to cause interest rate to fall, actions on the domestic credit act similarly in most of the CEMAC countries. But the potency of this loanable fund effect is also limited by various puzzling reactions of the price level and of the output level.

The rest of the paper is structured as follows: in Section 2, we are interested in the choice of the best measure of the policy stance in the CEMAC zone. A number of methodologies are therefore used to derive, if possible the variable which represent the best, the action of the monetary authority in the CEMAC. This exercise is useful regarding the methodology we adopt in the empirical part of the paper. In section 3, we describe our empirical methodology and our data. Empirical results are provided in Section 4 while Section 5 concludes.

\section{Measuring monetary policy in the CEMAC area.}

There seems to be a consensus among economists that monetary economics can significantly influence the course of the real economy, at least in the short run. Indeed, a spate of empirical research has confirmed the early finding of Friedman and Schwartz (1963) that movements in monetary policy actions are followed by movements in the real sector that may last for two years or more (Romer and Romer, 1989; Bernanke and Blinder, 1992; Christiano, Eichenbaum and Evans, 1994). As stated by Bernanke and Mihov(1998), accurate measurement of the effect of changes in monetary policy on the economy is essential, both for good policy-making and for choosing among alternative macroeconomic theories. However, those authors admit that there is less agreement between economists about how to measure the size and direction of changes in monetary policy. When Friedman (1963) stated that 'inflation is always and everywhere a monetary phenomenon", the conclusion for economic policy readily followed: Limit the growth of the money supply, and thereby limit the growth of prices, and the rate of inflation. As noted by Arestesis and Sawye(2004), this doctrine, put forward by monetarist economists did not continue its dominance of economic thinking for long. Many governments and central banks that focused on the growth of the money supply failed to hit their targets (Note 3). For Bernanke and Mihow(1998), secular changes in velocity brought about by financial innovation, deregulation, and other factors are a further barrier to using money growth rates alone as a measure of the direction of policy. Moreover, Sims (1980) and Litterman and Weiss (1985) in their respective works found that interest rates tend to absorb the predictive power of money. Specifically, a nominal interest rate appears to dominate money as a forecaster of output when added to a vector autoregression containing money. This low predictive power of money compared 
to interest rates is an important challenge of the traditional "money leads income" argument for monetary-policy effectiveness (Bernanke and Blinder, 1992). Also, the so-called new consensus of monetary economics, by adopting policy rules in the spirit of Taylor, has gradually de-emphasized money. Whether or not monetary policy must neglect money is a big debate among economists (see for e.g. Dotsey and Horstein, 2003; Nelson, 2003; Orlowski, 2004; Christiano, Motto and Massimo, 2007; Hafer, Haslag and Jones, 2007). Rather than enter into this debate, we will adopt in this section, a simple methodology proposed by Bernanke and Blinder (1992). In order to derive the best measure of monetary policy, Bernanke and Blinder(1992) use a multi-step methodology consisting on the information content of various candidates of the measure of monetary policy, the Federal Reserve's reaction function and the supply of and demand for bank reserves. We consider, in the case of our study, the first two steps.

\subsection{The information content of potential measures of monetary policy in the CEMAC.}

In order to address the issue of predictive power, Bernanke and Blinder (1992) consider nine real variables to be forecasted (industrial production, capacity utilization, employment, unemployment rate, housing starts, personal income, retail sales, consumption and durable goods orders). To forecast those variables, authors use two variables of broad money (M1 and M2) and three different interest rates (Federal Funds rate, Treasury bill rate, and the ten-year Treasury bond rate). In the CEMAC area, due to the problem of data availability, we only consider two macroeconomic variables (Real GDP and the consumer price index) (note 4). For those variables representing monetary policy actions, we use the rate offered by the central bank to second-tier banks for their refinancing process (Interest). That is, the so-called TIAO (taux d'interet d'appel d'offre); a measure of monetary aggregate (Money) and the level of Domestic credit by the banking industry to the private sector (Credit). The first variable, which is in fact the discount rate of the central bank, is used as the policy rate, for money market rates data are still unavailable. The second variable is the one considered as the measure of broad money (M2). This variable is used as an intermediary objective of the monetary policy alongside the level of credit to the economy. The use of the domestic credit to private sector as a measure of monetary policy stems from the fact that monetary authorities in the CEMAC region are interested in the evolution of this variable. Moreover, there is a long tradition which locates the cause of boom-bust cycles in excessive credit creation. A recent review of this tradition, and some evidence to support it, is provided in Eichengreen and Mitchener(2004) or Borio and Low(2002). All the data are from the IFS CD-ROM. We use quarterly data spanning from 1990.1 to 2006.4. Data for the Central African Republic and Equatorial Guinea are from 1990.1 to 2005.4 while those from the Republic of Congo cover the 1990.1 to 2007.4 period. We use the methodology of Boot, Feibes and Lisman(1967) to compute quarterly data of GDP.

We therefore begin with some useful Granger-causality tests. The output and price levels are forecasted by the monetary aggregate (Money), the policy interest rate (Interest) and the domestic credit to private sector (Credit). As most of our data show trends all over the period of interest, we accounted therefore for the non-stationary of our data. In fact, it is argued that when the variables have unit roots, the procedure for the identification of causal directions becomes more complex (Asteriou and Hall 2006). Following Granger and Lin (1995), the conventional Granger causality is not valid, because two integrated series cannot cause each other in the long run unless they are cointegrated. In such a case and after testing for the existence of cointegration, it is useful to reparametrize the model in the equivalent Error Correction Model. We therefore test for causality among the variables that are found to be cointegrated, using the Vector Error Correction Model (VECM) for the cointegrated variables. Specifically, we use two sets of models. The first model is composed of the real $\operatorname{GDP}(R G D P)$, the price level represented by the consumer price index(Price), the monetary aggregate(Money) and the domestic credit(Credit) while in the second we include Price, Money, Interest and Credit. According to Granger and Lin (1995), causality in the long run exists only when the coefficient of the cointegrating vector is statistically significant and different from zero. However, in our case, we apply variation deletion (F-type) tests for the coefficient in the cointegrating vector and for the lagged values of the variables in the VECM. For the first model (RGPD, Price, Money, Interest, Credit), we are interested mainly in the causal links between RGPD and the three candidates for monetary policy stance (Money, Interest, and Credit). Data for the price level (Price) are included for comparability with previous literature and because it is presumably real money or real interest rates that affect real variables. The same methodology is used in the second model to see the causal links between the price level and each of the candidates for the measure of monetary policy stance. These two variables (GDP and $C P I)$ were used by Dabla-Norris and Floerkemeier(2006) in the case of Armenia, a transition economy. The causality tests were run both on individual levels for each country and at an aggregated level with the data of the CEMAC. All data, except the interest rate, are in log. Compiled results are displayed in Table 1 and Table 2. 
Results in Table 1 show that only the Interest rate (Interest) Granger-causes GDP in Cameroon and to a lesser extend in Gabon. However, none of the monetary policy indicators Granger causes GDP in the other countries. The monetary aggregate (Money) is close to Granger-cause GDP at the significance level of $10 \%$ when considering the whole CEMAC zone.

Results displayed in Table 2 indicate that the Interest rate (Interest) is the best predictive variable for CPI in Cameroon, followed by Credit. Money has any predictive power on CPI. However, Money is the only variable that causes CPI (Price) in Central African Republic, while Credit seems more relevant in Chad. Once more, all the three variables fail to predict CPI in Congo, Equatorial Guinea and Gabon. It's also worth nothing that Interest is the only variable that Granger-causes CPI when the whole CEMAC is considered.

As stated by Bernanke and Blinder (1992) a serious drawback of the Granger- causality approach is that variables are not orthogonal. That is why Sims (1980) and Litterman and Weiss (1985) advocate the use of a different measure of predictive power, one that is constructed from a VAR with orthogonalized residuals: the percentage of the variance of the forecasted variable attributed to alternative right-hand-side variables at different horizons. According to Bernanke and Blinder (1992) the ordering of explanatory variables is likely to influence the results and therefore constitutes one of the drawbacks of this method. In our case we ran for each forecasted variable in each country, 3 VAR specifications which enabled us to alter the order of the candidate variables. VAR specifications in order to forecast GDP are as follows: 1(RGDP, Price, Money, Interest, Credit) 2.(RGDP, Price, Interest, Credit, Money), (RGDP, Price, Credit, Money, Interest). For the price level, VAR specifications are quite the same, at the only difference that we removed $R G D P$. Here also, we accounted for the non-stationary of our series by considering not simple $V A R s$, but $V A R s$ with stationary variables. In tables 3 and 4 , we only report for each forecasted variable, their variance decomposition issued from specification 1 at a two-year horizon. Meanwhile, our results show that changing the ordering of the variables has no significant incidence.

Our results for Cameroon show that Interest has the highest predictive power in all the specifications for $R G D P$ and Price. It outperforms both Money and Credit. The policy rate (Interest) also outperforms the other candidates in predicting $R G D P$ in Central African Republic. In the same country, Money appears to be by far the best predictive variable for Price. This feature holds for all VAR specifications.

Real activity in two countries (Chad and Equatorial Guinea) seems to be well forecasted by movements in bank credit. Credit in the two countries has the highest variance in the prediction of both RGDP and Price respectively.

For Congo, results show that $R G D P$ and Price both are better predicted by the policy rate in all the VAR specifications, as is the case in Cameroon.

In Gabon, the variance of $R G D P$ attributed to Credit is superior to that Money and Interest in 2 specifications. When Interest is placed immediately after the price level, its variance is superior to that of Credit and Money. This feature changes with the variance decomposition of Price. Here on the contrary, it's Interest which outperforms the two other variables.

Finally, results in the supranational level show that Money has the best predictive power on $R G D P$. On the other side, the policy rate is the best predictive variable for Price

To summarize, according to the variance decomposition methodology, the policy rate emerge as the best candidate for monetary policy stance in almost four of the countries in the CEMAC zone (Cameroon, Central African Republic, Congo and to a lesser extent Gabon). Domestic credit by the banking industry to the private sector on its part is relevant in Chad and Equatorial Guinea. Money is an important determinant of the variance of $R G D P$ in the regional level and for the $C P I$ in Central African Republic.

We now turn to the Reaction function of the monetary authority.

\subsection{The Reaction Function of the Monetary Authority}

Bernanke and Blinder (1992) argue that if the Federal Funds rate or some related variable is an indicator of the Federal Reserve's policy stance, and if the Fed is purposeful and reasonably consistent in its policy-making, then the funds rate should be systematically related to important macroeconomic target variables like unemployment and inflation. They then estimate policy reaction functions in the form of

$P_{t}=D_{0} Y_{t}+D_{1} Y_{t-1}+G P_{t-1}+\eta_{t}$

Where $\mathrm{Y}$ is a vector of nonpolicy variables, $\mathrm{P}$ is a vector of policy variables, and $\mathrm{v}$ is a disturbance variable. 
As in Bernanke and Blinder (1992) we estimate a series of three-variable VARs using one of our indicators of monetary policy, the price level and real output. Once more, all variables, except Interest are in log. The sample periods are the same as in the previous sub-section. As all of our variables (except for the policy interest rate) are integrated of order 1, we estimate VARs with only stationary variables. Figure 1(not reported) displays the implied impulse-response functions of the various measures of monetary policy to shocks to RGDP and Price for each country in the entire CEMAC area.

Results in Cameroon look like plausible reaction functions. Although the interest rate remains below its equilibrium level during the first quarter after a positive shock on $R G D P$, it rises in the second quarter and remains positive till the end of the period. Also, with an inflation shock, the interest rate rises for two quarters, and then falls below its equilibrium level afterwards. A positive shock on output entails a decrease in the monetary aggregate; however, the response of this variable to an inflation shock is not as expected. Money increases for quite the whole period. Positive shocks on both $R G D P$ and Price all seem to drive down the domestic credit to the private sector by banks and for very long periods. In the case of shock on RGDP, Credit first increases slightly during the first quarter, and then falls below its equilibrium level till the end of the period. With an inflation shock, Credit remains negative for about 4 quarters before following a path close to the equilibrium level till the end of the period.

In Central African Republic, impulse responses of the policy rate after positive shocks on $R G D P$ and Price respectively are plausible. Interest increases at least for one quarter (3 quarter with a $R G D P$ shock) before declining till the end of our period of concern. On the contrary, the responses of Money to output and inflation shocks are counter-intuitive. In both case, Money rather increases than declines and the effect is persistent, especially with an inflation shock. Macroeconomics shocks do not produce the awaited reaction from the domestic credit. Although Credit declines during the first quarter with an output shock, it increases as from the second period and this effect is persistent. Inflation shock leads to more fluctuations in Credit.

Impulse response functions for Chad show that none of our three policy variables is relevant for this country. While the policy rate decrease after macroeconomic shocks, the domestic credit on its part increases persistently as is the case with inflation shock (and at least 2 quarters with an output shock). Money also increases for two quarters after an inflation shock, before declining afterwards. With an output shock, this variable shows more fluctuations, but as expected, declines at the first quarter.

In Congo the policy rate, although declines during the first quarter after a shock on $R G D P$, quickly increases beginning from the second quarter and remains positive for the rest of the period. Interest also rises the first 3 months after a shock on Price, before decreasing afterwards. Impulse responses of Money after macroeconomic shocks are not interesting. The variable persistently increases after those shocks. Credit also observes quite the same path. Even if it declines in the second quarter following an output innovation, this variable increases in the third period and remains above its equilibrium level till the end of the period.

The policy rate in Equatorial Guinea increases for about 9 months following an output innovation. On the contrary, Interest declines shortly after an inflation shock and for the whole period. After a positive shock on $R G D P$, Money declines for two successive quarters, the second and the third, but increases during the first three months. Money also rises during the first two quarters following an inflation shock. Credit declines immediately after a shock on GDP, but raises at the second quarter and stay above its equilibrium level till the end of our period of 8 quarters. This tendency is reversed with an innovation on Price.

Finally in Gabon, interest rate goes up during the first period following an inflation shock and falls afterwards. The same interest rate decreases during the first 2 quarters following an output shock, rises slightly at the third quarter before declining again at the fourth. Money remains above its equilibrium with both output and inflation shocks and for the entire period (it declines slightly at the first quarter following a positive innovation on output). Credit on its part only decreases with some lags after both output and inflation shocks. But this effect, if quite long lasting for inflation shocks (about 3 quarters) it is rather thin for output shocks.

At the general level, our results indicate that only the interest rate can be treated as a variable representing the stance of monetary policy in the CEMAC area. Money and Credit do not lead to such conclusions because their respective responses to output and inflation shocks are counter-intuitive.

Overall, when we refine our methodology, the policy rate (Interest) is likely to be considered as a good proxy of the monetary policy stance in the CEMAC area. This tendency, already present with the variance decomposition methodology, is confirmed by the impulse response methodology. In both case, Interest appears as the best variable representing the monetary policy stance in at least four countries. The same variable is also the best 
forecaster of the Price in the regional level and reacts also as expected to both output and inflation shocks. Results of Money and Credit are not as satisfactory as those of Interest.

\section{Empirical Methodology and Data description}

The aim of our paper is to estimate the liquidity effect and subsequently the loanable funds effect in the countries of the CEMAC zone. The issues concerning these two items in the CEMAC countries are:

Does the Conventional wisdom hold in the countries of the CEMAC area? Is this effect long lasting or not?

Are there some differences among countries in the way the liquidity effect performs in the region?

As the first instance of the higher monetary growth appears to take the form of an increase in the flow supply of loanable funds, how does this increase affect the interest rate?

To provide answers on the above questions, we use a methodology based on Vector autoregressive models. Specifically, we estimate a series of four-variable VARs. For the liquidity effect, VARs include the Policy Interest rate (Interest), the monetary aggregate, (Money), the Real output (RGDP) and the Consumer Price Index (Price). To assess the loanable effect, we use the Domestic Credit to the private sector by banks (Credit), Interest, RGDP and Price. When assessing the liquidity effect, we estimate two sets of VARs corresponding each to two classes of identification assumptions about monetary policy disturbances as proposed by Christiano and Eichenbaum(1991). The first class, labeled M-rules by Christiano and Eichenbaum(1991) is defined by the assumption that unanticipated changes in monetary policy can be measured by some orthogonalized component of the innovation to the monetary aggregate. The second class, called R-rules, rather considers that unanticipated changes in monetary policy can be measured by some orthogonalized component of the innovation to the policy interest rate. In each of these classes of assumptions, we estimate five VARs, where each VAR corresponds to a certain Wold causal interpretation of the data (Note 5) In line with Christiano and Eichenbaum(1991) the baseline VAR in the class of M-rules is as follows:

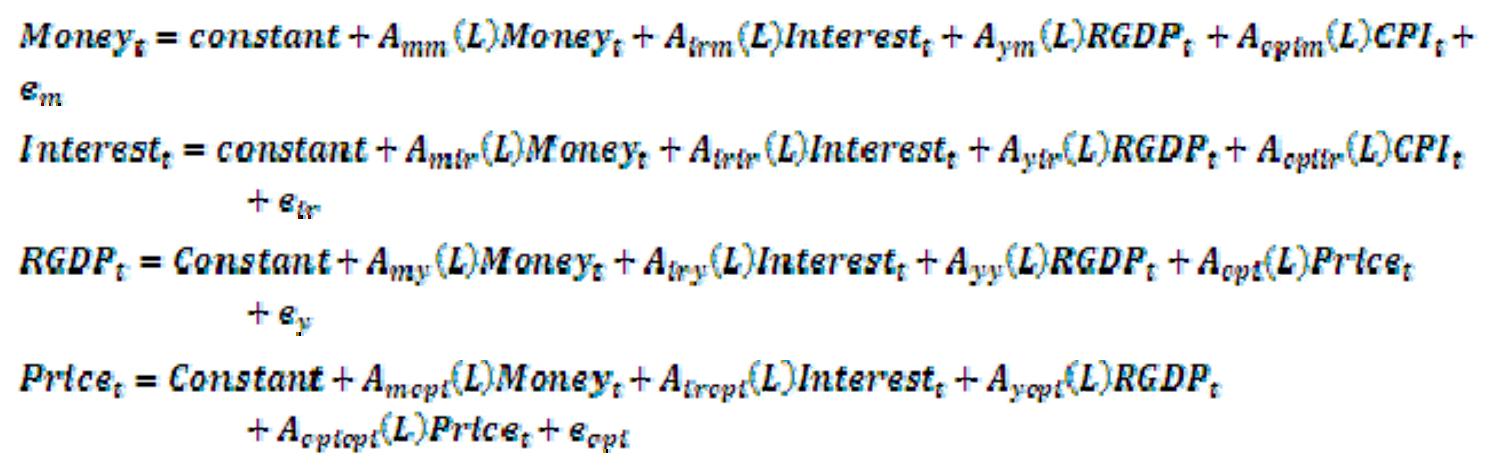

Where the number of lags is $\mathrm{K}+1$ (the equivalent of $\mathrm{K}$ lags in difference), and (e) is the orthogonal innovation or the exogenous shock in each equation. The subscripts m,ir,y,and cpi stand for money, interest rate, output and price respectively. As noted by Christiano and Eichenbaum(1991), the Wold ordering underlying this first VAR is $\{$ Money, Interest, RGDP, Price\}. This corresponds to the assumption that the contemporaneous portion of the monetary authority's feedback rule for setting Money does not involve Interest, RGDP or Price. This identification scheme is consistent with Barro(1981), Mishkin(1982), King(1982), Leeper(1992) Christiano and Eichenbaum(1991a, 1992b) Gordon and Leeper(1991), Christiano et al.(1994) and Guirguis(1999). The other VARs closely follow the above model specification, with each having a hypothesis about the nature of the contemporaneous portion of the monetary authority feedback rule for its policy instruments. Therefore, the Wold ordering underlying the second VAR is $\{$ Interest, Money, RGDP, Price $\}$, so that the unanticipated change in monetary policy is measured as that portion of the innovation in Money which is orthogonal to the innovation in Interest. This corresponds to the assumption that the contemporaneous portion of the monetary authority's feedback rule involves Interest, but not RGDP or Price. In the third VAR specification, the Wold ordering $\{$ RGDP, Money, Interest, Price $\}$ indicates that the monetary authority's feedback rule for Money involves RGDP, but not Interest or Price. The fourth VAR specification, which Wold ordering is \{Price, Money, Interest, RGDP $\}$ admits the assumption that the contemporaneous portion of the monetary authority's feedback rule for Money involves Price, but not Interest or RGDP). finally, the Wold ordering underlying the fifth VAR is \{Price, $R G D P$, Money, Interest $\}$, so that the unanticipated change in monetary policy is measured as that portion of the innovation in Money which is orthogonal to innovations in Price and RGDP; that is, in setting Money the monetary authority looks at Price and $R G D P$, but not Interest.

Quite the same VAR specifications and Wold causal ordering are applied when moving from M-rules to R-rules. But in this class of identification scheme, unanticipated innovations on Interest rather than Money are considered as unanticipated policy shocks. Here, the VAR wold orderings are respectively \{Interest, Money, RGDP, Price\}, 
$\{$ Money, Interest, RGDP, Price $\},\{R G D P$, Interest, Money, Price $\},\{$ Price, Interest, Money, RGDP $\},\{$ Price, $R G D P$, Interest, Money\}.

For the investigation of a potential loanable funds effect, we estimated five VARs which Wold orderings are respectively \{Credit, Interest, RGDP, Price\}, \{Interest, Credit, RGDP, Price\}, \{RGDP, Credit, Interest, Price\}, $\{$ Price, Credit, Interest, $R G D P\}$, and \{Price, RGDP, Credit, Interest\}.

At each step (liquidity effect and loanable funds effect) we derive impulse-response functions from the estimated VARs to analyze the two effects. We considered both individual countries and the whole CEMAC zone.

Our data and time span for each country remain the same as those in section 2 . We also correct for the non-stationary of the data, as proposed by Guirguis(1999). But contrary to Guirguis(1999) who uses quite a long series of monthly data( 1960:1-1993:12) we didn't estimate rolling impulse-response functions. Therefore, our impulse-response functions are derived from VARs with stationary variables and with a time horizon of eight quarters.

\section{Empirical Results}

We first analyze the liquidity effect with M-rules, then the liquidity effect with R-rules and at last, the loanable fund effect.

\subsection{The liquidity effect of monetary policy in the CEMAC zone with M-rules.}

As described in Section 3, the class of M-rules considers that the monetary policy disturbance corresponds to the statistical innovation in Money. Results obtained in this framework are displayed in Table 5. Each row of the table summarizes results obtained from the impulse responses of our different VAR specifications for each country (Detail results are available from the author). Column 2 shows the summarized results for the liquidity effect. It should be recalled that for the Conventional wisdom, unanticipated expansionary monetary policy shocks cause transient but persistent decrease in real and nominal interest rates and a persistent increase in the level of employment and output (Christiano and Eichenbaum, 1992). Therefore, a part from the reaction of the interest rate, we also report those of the output and price levels.

The results in Cameroon reveal some evidence of the liquidity effect and this effect is immediate and long lasting. In all but one VAR specifications, Interest always remains below its equilibrium for many quarters after an innovation in Money and the effect is immediate.

The reactions of the other variables (RGDP and Price) are also important. Our results show that the price level always rises persistently (at least for 4 quarters) following a positive innovation in the monetary aggregate. On the contrary, the output level always declines for a long time period following an unanticipated monetary policy and this is considered as a puzzle.

In Central African Republic the interest rate always decline for quite two years following a positive shock on Money. However, this downward movement is preceded by an increase of the interest rate -the so-called liquidity puzzle--during the first quarter. In most of our specifications the output level only increases during the first 3 months following the monetary policy shock, declines in the second quarter and then follows a path close to the equilibrium till the end of our period of concern. The reaction of the price level is as expected, as this variable always rises immediately after a positive innovation on Money.

The liquidity puzzle in Central African Republic is also present in Chad. And as is the case previously, after an increase in the first quarter, the interest rate persistently decreases for the rest of the period. Also, if the reaction of the price level is as expected ( 2 to 3 quarters increase), the impulse response functions of the output level are sometimes counter-intuitive.

In Congo our results show that there is some evidence of a liquidity effect. In quite all VAR specifications, the interest rate always goes below its equilibrium level immediately after a monetary shock and for a long time period (at least 5 to 6 quarters). Although in the third and fifth specification there is a long lasting decline in the output level, the rest of our results reveal an output increase after an unanticipated monetary policy (about six months). Monetary actions entail more fluctuations in the price level; with a slight increase during the first quarter followed by a slump in the second and third, then another increase in the fourth quarter and so on. For the last two VAR specifications, the price level declines immediately during the first 3 quarters following the monetary innovation.

According to the results from the impulse responses summarized in Table 5, there is a clear evidence of the liquidity effect in Equatorial Guinea. Interest always persistently declines after a positive shock on Money. Moreover, this positive shock on Money is always followed by an output level increase for about 2 quarters. As 
is the case in Congo, monetary policy actions cause more fluctuations in the price level with sometimes, the presence of a price puzzle.

In Gabon, the interest rate reacts as expected after an unanticipated monetary policy action. It always immediately and persistently declines for the entire period. However, this liquidity effect sometimes goes along with a price puzzle effect (Fourth and Fifth VARs) and some counter-intuitive reactions of the output level

Overall, our results indicate that the conventional hypothesis holds in the CEMAC area, when we use the class of M-rules. However, the liquidity effect in this case is sometimes preceded by a liquidity puzzle in the first quarter. Moreover, the behaviors of the output level and the price level are sometimes puzzling.

\subsection{The liquidity effect of monetary policy in the CEMAC area with R-rules.}

With R-rules, all of the identification schemes share the assumption that unanticipated change in monetary policy is some orthogonalized component of the innovation to the interest rate. This idea is contained in a number of studies (McCallum, 1983; Bernanke and Blinder, 1992; and Sims, 1986, 1992) where authors argue that, at least relative to high-order monetary aggregates like M1 or M2, the innovation in interest rates is a better measure of unanticipated changes in monetary policy than the innovation to the stock of money. Each identification scheme corresponds to a certain Wold causal interpretation of the data, as in the previous sub-section. In the first Wold ordering, as assumed by Bernanke and Blinder (1992) or Sims $(1986,1992)$, the contemporaneous portion of the feedback rule for setting Interest does not include Money, RGDP or Price. However, to enhance the power of the results, Christiano and Eichenbaum(1991) consider four alternative Wold causal chains, similar to those described when Money is the measure of the monetary stance. Therefore, our five Wold causal ordering are respectively \{Interest, Money, RGDP, Price $\},\{$ Money, Interest, RGDP, Price $\},\{R G D P$, Interest, Money, Price\}; \{Price, Interest, Money, RGDP\}; and \{Price, RGDP, Interest, Money\}. Results, contained in Table 6, summarize the impulse response functions of Money, RGDP and Price following an unanticipated change in monetary policy (Interest) for the various VAR specifications. As previously, we set the time horizon at 8 quarters. Detailed results are available from the author at request.

Globally, there is no presence of a real liquidity effect in the CEMAC, both on individual and regional levels, when we consider the class of R-rules. Equatorial Guinea is the only country where the monetary aggregate significantly and persistently declines after a positive innovation on the policy rate. The same tendency is observed with the price level. But responses of the output level are always counter-intuitive. The three last specifications show a slight liquidity effect in Gabon, but this effect is undermined by persistent price puzzles and bad output reactions. Liquidity and price puzzles are also present in Cameroon and Congo but contrary to Congo, the output level reacts as expected in Cameroon. Central African Republic and Chad have the worst results in this category of R-rules. It should be recalled that those two countries are also the weakest economies of the CEMAC.

We now briefly resume our findings about the loanable funds effect.

\subsection{The loanable funds effect in the CEMAC countries.}

Friedman and Schwartz (1982) affirm that the increased rate of the monetary growth comes undoubtedly from the banking system. Aggressive open market purchases by the central bank by adding to the reserves of commercial banks, is likely to induce them to expand more rapidly their loans and investments. Consequently, Friedman and Schwartz (1982) consider that at the beginning, the higher rate of monetary growth appears to take the form of an increase in the flow supply of loanable funds. Whether this increase in the supply of loanable funds produces a once-for-all (the expression is from Friedman and Schwartz) drop in the interest rate is the so-called loanable funds effect. In this sub-section, we verify this assumption in the framework of the CEMAC zone. For this purpose, we re-estimate the VARs specifications corresponding to the class of M-rules of the liquidity effect. But, instead of Money, we use the Domestic credit to the private sector by the banking system (credit). An advantage of using this variable is its ability to represent in some extent the monetary authority actions in the CEMAC area. Dynamic responses of the interest rate are therefore derived from shocks to Credit. Those responses, alongside the responses of the output level and the price level are summarized in Table 7. The time spans, the period horizon of the impulse-response functions remain the same as in the two previous sub-sections.

According to our results, the loanable funds effect is effective in 4 of the 6 countries of the CEMAC. Those include Cameroon, Chad, Equatorial Guinea and Gabon. This tendency is confirmed with the aggregated data in the regional level. Here, not only does the interest rate decline for 2 quarters on average after an innovation on the domestic credit, the output and price levels all rise substantially and persistently. Such a result is worth 
emphasizing for two reasons: 1) our own calculations show that the average domestic bank credit to the private sector in percentage of the GDP is very low in the CEMAC area (only $6 \%$ on average for the six countries). 2) It has been demonstrated that banks in the CEMAC hold high excess reserves (See for example Saxeguaard, 2006) making them indifferent from any monetary policy action. Therefore, any measure willing at increasing the available loanable funds to the private sector by the banking sector shall produce good results. Nevertheless, the loanable funds effect operates with price puzzles in Cameroon and Equatorial Guinea. Moreover, in all countries where this effect is operates, the impulse responses of the output level are sometimes counter-intuitive.

\section{Conclusion.}

The main purpose of our paper was to study the liquidity effect of the monetary policy actions in the CEMAC countries. Our investigations led us to some important findings. First, we noted that, of the three variables that are likely to be considered as those representing the stance of monetary policy in the CEMAC, it is the policy interest rate (TIAO) that outperforms the domestic credit and the monetary aggregate.

Second, we assessed the liquidity effect of monetary policy in the CEMAC countries using two different sets of identification assumptions. The class of assumptions which consider that unanticipated changes in monetary policy can be measured by some orthogonalized component of the innovation to the monetary aggregate is more reliable in our context, to the study of the liquidity effect in the CEMAC. Using this class of assumptions, we demonstrate that the liquidity effect operates both in the individual countries and in the entire region. Therefore, the central bank in the region can stimulate the economy by increasing the supply of money and thereby lowering interest rates. However, the big challenge for the monetary authorities in this process is to harmonize the effect across countries where many differences appear. Moreover, the central bank should also endeavor to correct or eliminate some important puzzles that are likely to appear after a monetary expansion. If the main objective is to stimulate the economy, monetary expansions should therefore avoid output slowdowns and to a lesser extent, price level decreases. As those puzzles are present in quite all the countries of the CEMAC, they could undermine the action of the monetary authorities.

Third, although the policy rate appear to be a good measure of the monetary policy stance in the CEMAC area, the use of this variable as such does not lead us to good results about the liquidity effect. Concretely, if unanticipated changes in monetary policy can be measured by some orthogonalized component of the innovation to the interest rate, the liquidity effect does not operate in the CEMAC countries. And even in the countries this liquidity effect takes place, it is undermined by serious price and output puzzles. As argued by Strongin(1995), there a clear need of demonstrated empirical link between the central bank policy actions and interest rate movements if one wishes to attribute innovations in interest rates to monetary policy actions. This issue is a big concern in the CEMAC area where the discount rate (TIAO) is still fixed by the Chairman of the BEAC (Note 6), all that could limit the potency of this variable as a reel policy rate

Finally, it appears that an increase in the flow supply of loanable funds has the expected decline in interest rate for most of the countries of the CEMAC. Therefore, besides the monetary aggregate, the credit level can be used by monetary authorities for economic stimulation purpose. However, the different puzzles that appear here most be attenuated or avoided, as is the case with the conventional wisdom. In both cases, actions must be undertaken in order to reduce economic disparities among the six countries and enhance the potency of monetary policy measures in the region. Those actions might include some macroeconomic convergence criteria, the enhancement of a real economic and financial integration in the region as is the case in the European Union, the model of economic union which inspires the CEMAC.

\section{References}

Arestis, P. and Sawyer, M. (2004). Re-examining Monetary and Fiscal Policy for the $21^{\text {st }}$ Century. Edward Elgar Publishing Limited.

Asteriou.D. and Hall.S.G.(2006,2007). Applied Econometrics: A Modern Approach Using Eviews and Microfit. Revised Edition. Palgrave. MacMillan.

Atkeson, A. F. A. and Kehoe, P.J. (2002). Money, interest Rates and Exchange rates with Endogenously Segmented Markets. Journal of Political Economy 110(1), 73-112.

Barro, R. J. (1981). Unanticipated Money Growth and Economic Activity in the U.S. In Money, Expectations and Business Cycles. Academic Press, New York.

Bernanke, B. and Blinder, A.(1992). The Federal Funds Rate and the Channels of Monetary Transmission. The American Economic Review, Vol.82. No.4, pp. 901-921. 
Bernanke,B.S and I. Mihov (1998) “ Measuring Monetary Policy”, The quarterly Journal of Economics, vol. 113, No.3 pp. 869-902.

Boot, J.C.G., Feibes,W., and Lisman, J.H.C. (1967). Further Methods of Derivation of Quarterly Figures from Annual Data. Journal of the Royal Statistical Society. Series C(Applied Statistics), Vol.16, No.1, pp.65-75.

Borio, C. and Low, P. (2002). Asset Prices, Financial and Monetary Stability: Exploring the Nexus", BIS Working Papers No.114

Braun, R.A. and Shioji, E. (2003. Monetary Policy and Economic Activity in Japan and the United States. CIRJE Discussion Papers.

Cagan, P. (1972). The Channels of Monetary Effects on Interest Rates(NBER, New York, NY)

Christiano, L. J. (1991). Modeling the Liquidity Effect of a Money stock. Federal Reserve Bank of Minneapolis Quarterly Review 15, 1-34.

Christiano, L.J. and Eichenbaum, M. (1992a). Liquidity Effect and Monetary Policy Transmission Mechanism. NBER Working Paper No.3974.

Christiano. L. J. and Eichenbaum. M. (1992b). Liquidity Effects, Monetary Policy and the Business Cycle. NBER Working Paper No.4129.

Chiristiano, L., Eichenbaum, M. and Evans, C. (1998). Monetary Policy Shocs: What have We Learned and to What end? NBER Working Paper 6400.

Christiano, L., Motto, R., and Rostagno, M. (2007). Two Reasons why Money and Credit May be Useful in Monetary Policy. NBER Working Paper No.13502.

Christiano, L. J. and Eichenbaum, M. (1991). Identification and the Liquidity Effect of a Monetary Policy Shock. NBER Working Paper No.3920.

Christiano, L. and Eichenbaum, M. (1995). ). Liquidity Effects, Monetary Policy and the Business Cycle. Journal of Money, Credit and Banking 27(4): 1113-1136

Dabla-Norris, E. and H. Floerkermeier. (2006) "Transmission Mechanism of Monetary Policy in Armenia: Evidence from VAR analysis”, IMF Working Paper, International Monetary Fund.

Dotsey, M. and Hornstein, A. (2003). Should a Monetary Policymaker Look at Money? Journal of Monetary Economics 50, 547-579.

Edmond, C. and Weill, P.O. (2005). Models of the Liquidity Effect. In Durlauf, S.N. and Blume, L.E., The New Palgrave Dictionary of Economics, forthcoming.

Eichengreen, B. and Mitchener. K.J. (2004) The Great Depression as a Credit Boom Gone Wrong. In Field, Alexander., ed. Research in economic history. Volume 22. Co edited by Gregory Clark and William A. Sundstrom. Oxford; Amsterdam and San Diego: Elsevier, JAI, 183-237.

Friedman, M. (1963). Inflation: Causes and Consequencs. Asia Publishing House, New York.

Friedman, M. (1968). The Role of Monetary Policy. American Economic Review 58, 1-17.

Friedman, M and A. J. Schwartz (1963) “A Monetary History of the United States, 1867-1960”, Princeton, NJ: Princeton University Press.

Friedman, M. and Schwart, A.J. (1982). Monetary trends in the United States and the United Kingdom (University of Chicago Press. Chicago, IL).

Fuesrt, T. S. (1992). Liquidity, loanable funds, and real activity. Journal of Monetary Economics 29, 3-24.

Giovannini, S. and Labadie, P. (1991). Asset Prices and Interest Rates in Cash-in-advance Models. Journal of Political Economy 99(6), 1215-1251.

Granger, C.W.J. and Lin. J. (1995). Causality in the Long-run. Econometric Theory, 11, pp. 530-36.

Greenwood, J. and Huffman, G.W. (1987). A Dynamic Equilibrium Model of Inflation and Unemployment. Journal of Monetary Economics 19, 203-228.

Grossman, S. and Weiss, L. (1983). A transactions-based model of the monetary transmission mechanism. American Economic Review 73, 871-880.

Guirguis, H.S. (1999). Properly Estimating the Liquidity Effect: Why Accounting for Stationarity and Outliers is Important. Journal of Economics and Business 51, 303-314. 
Hafer, R.W., Haslag, J.H. and Jones.G. (2007). On Money and Output: Is Money Redundant? Journal of Monetary Economics 54, 945-954

Hodrick, R. J., Kocherlakota, N. and Lucas, D. (1991). The Variability of Velocity in Cash-in-advance Models. Journal of Political Economy 99(2), 358-384.

King, R. (1991). Money and Business Cycles. Unpublished Manuscript, University of Rochester.

Leeper, E.M. (1992). Facing up to our Ignorance about Measuring Monetary Policy Effects. Economic Review 77: $1-16$.

Leeper, E. M. and Gordon, D. B. (1992). In Search of The Liquidity Effect. Journal of Monetary Economics 29, 341-369.

Litterman, R.B. and Weiss.L. (1985). Money, Real Interest Rates, and Output: A Reinterpretation of postwar U.S. data. Econometrica 53, 129-156.

Lucas, R.E. Jr. (1990). Liquidity and Interest Rates. Journal of Economic Theory 50, 237-264.

McCallum, B.T. (1983). A Reconsideration of Sims, Evidence Concerning Monetarism. Economic Letters, 13, Nos. 2-3, 167-171.

Mishkin, F. (1982). Monetary Policy and Short Term Interest Rates: An Efficient Markets Rational Expectations Approach

Nelson. E. (2003). The Future of Monetary Aggregates in Monetary Policy Analysis. Journal of Monetary Economics 50, 1029-1059

Orlowski, L. T. (2004). Money Rules for Monetary Convergence in the Euro. Journal of Policy Modeling 26, 817-837.

Romer,C. And Romer, D. (1989). Does Monetary Policy Matter? A new test in the Spirit of Friedman and Schwartz. NBER Macroeconomic Annual, 4, 121-170.

Sims, C. A. (1980). Comparison of Interwar and Postwar Business Cycles: Monetarism Reconsidered. American Economic Review Papers and Proceedings 70, 250-257.

Sims, C.A. (1986). Are Forecasting Models Usable for Policy Analysis? Federal Reserved Bank of Minneapolis Quarterly Review, Winter, 2-16.

Sims, C.A. (1992). Interpreting the Macroeconomic Time Series Facts: The Effects of Monetary Policy. European Economic Review 36, 975-1000.

Strongin, S. (1994). The Identification of Monetary Policy Disturbances Explaining the Liquidity Puzzle. Journal of Monetary Economics 35, 463-497.

\section{Notes}

Note 1. A survey of the liquidity puzzle can be found in Reichenstein(1987)

Note 2. CEMAC (Communaute Economique et Monetaire de l'Afrique Centrale) is an economic and monetary union. Member states include Cameroon, Central African Republic, Chad, The Republic of Congo, Equatorial Guinea and Gabon.

Note 3. An exception on can be made with the cases of the Bundesbank in Germany and the National Swiss Bank in Switzerland which monetary targeting strategies are considered to have well performed( see for more details)

Note 4. The two variables were also used by Dabla Norris and Holger Floerkemeier(2006)

Note 5. Details about the methodology are found in Christiano and Eichenbaum) (1991).

Note 6. BEAC is the French acronym for Banque des Etats de l'Afrique Centrale, the central bank of the CEMAC area. 
Table 1. Marginal Significance Levels of Monetary Policy Indicators for GDP

\begin{tabular}{|l|l|l|l|}
\hline & Money & Interest & Credit \\
\hline Cameroon & 0.72 & 0.031 & 0.23 \\
\hline Central African Republic & 0.67 & 0.43 & 0.76 \\
\hline Chad & 0.93 & 0.80 & 0.12 \\
\hline Congo & 0.95 & 0.107 & 0.49 \\
\hline Equatorial Guinea & 0.49 & 0.90 & 0.34 \\
\hline Gabon & 0.48 & 0.092 & 0.93 \\
\hline CEMAC & 0.1058 & 0.98 & 0.11 \\
\hline
\end{tabular}

Notes: The entries across each row are the marginal significance levels of each monetary policy variable indicated in the column. Results are obtained using Error Correction Models which account for non-stationary and cointegration among the variables. We apply variation deletion (F-type) tests for the coefficient in the cointegrating vector and for the lagged values of the variables in ECM. We utilized the Scharz Bayesian Information criterion to select the appropriate lags of the VECMs. Due to the short data base, lags vary between 2 and 3 in all countries. We used Quarterly data from 1990.1 to 2007.4. All data, excluding the interest rate are in log . Interest is the Discount rate of the Central bank, while Money stands for broad money (M2) according to the IFM. Data are from the International Financial Statistics CD-Rom of the IMF.

Table 2. Marginal Significance Levels of Monetary Policy Indicators for the CPI

\begin{tabular}{|l|l|l|l|}
\hline & Money & Interest & Credit \\
\hline Cameroon & 0.25 & 0.0002 & 0.0056 \\
\hline Central African Republic & 0.0039 & 0.22 & 0.40 \\
\hline Chad & 0.54 & 0.97 & 0.064 \\
\hline Congo & 0.34 & 0.85 & 0.95 \\
\hline Equatorial Guinea & 0.40 & 0.52 & 0.14 \\
\hline Gabon & 0.73 & 0.24 & 0.56 \\
\hline CEMAC & 0.87 & 0.014 & 0.15 \\
\hline
\end{tabular}

Table 3. Variance Decomposition of GDP

\begin{tabular}{|l|l|l|l|l|l|}
\hline & RGDP & Price & Money & Interest & Credit \\
\hline Cameroon & 74.66 & 8.54 & 2.56 & 9.07 & 5.15 \\
\hline Central African Republic & 91.14 & 6.73 & 0.86 & 0.91 & 0.34 \\
\hline Chad & 81.63 & 7.69 & 0.47 & 0.97 & 9.21 \\
\hline Congo & 91.99 & 5.28 & 0.35 & 1.63 & 0.71 \\
\hline Equatorial Guinea & 86.48 & 0.11 & 3.44 & 1.90 & 8.06 \\
\hline Gabon & 91.41 & 1.30 & 1.24 & 2.96 & 3.05 \\
\hline CEMAC & 73.85 & 11.31 & 7.26 & 3.04 & 4.51 \\
\hline
\end{tabular}

Notes: Entries are the percentages of the variance of GDP attributed to itself, the CPI and each monetary policy indicator at a horizon of 8 quarters. Estimates are based on vector autoregressions with the same variables and lags as in the case of Granger-causality tests. The ordering of the variables in the variance decomposition is the same as the ordering (left to right) of the columns. Results of the alternative ordering schemes are not displayed, but are available from the authors in request. All the variables, except Interest are in log and only stationary data are included in the VARs. Data, which are quarterly, are from the IFS CD-Rom.

Table 4.Variance Decomposition of Price

\begin{tabular}{|l|l|l|l|l|}
\hline & Price & Money & Interest & Credit \\
\hline Cameroon & 82.78 & 0.94 & 11.46 & 4.80 \\
\hline Central African Republic & 68.07 & 26.08 & 3.24 & 2.59 \\
\hline Chad & 80.30 & 1.60 & 2.80 & 15.28 \\
\hline Congo & 94.01 & 2.16 & 2.97 & 0.84 \\
\hline Equatorial Guinea & 79.99 & 4.75 & 4.88 & 10.36 \\
\hline Gabon & 96.44 & 0.43 & 1.71 & 1.40 \\
\hline CEMAC & 93.97 & 1.76 & 2.81 & 1.44 \\
\hline
\end{tabular}

Notes: Entries are the percentages of the variance of CPI attributed to CPI itself and each monetary policy indicator at a horizon of 8 quarters. Estimates are based on vector autoregressions with the same variables and lags as in the case of Granger-causality tests. The ordering of the variables in the variance decomposition is the same as the ordering (left to right) of the columns. Results of the alternative ordering schemes are not displayed, but are available from the author in request. All the variables, except Interest are in log and only stationary data are included in the VARs. Data, which are quarterly, are from the IFS CD-Rom. 
Table 5: Liquidity Effect with M-Rules

\begin{tabular}{|l|l|l|l|}
\hline & Liquidity Effect & Response of GDP & Response of CPI \\
\hline Cameroon & Yes & Puzzles & Expected \\
\hline Central AF REP & Yes(with some puzzles & Some puzzles & Expected and long lasting \\
\hline Chad & Yes but with some lags & Some puzzles & As Expected \\
\hline Congo & Yes & As Expected & Some puzzles \\
\hline Equatorial Guinea & Yes & As Expected & Some puzzles \\
\hline Gabon & Yes & Some puzzles & Some Puzzles \\
\hline CEMAC & Yes but with some puzzles & As Expected & Some Puzzles \\
\hline
\end{tabular}

Note: The entries in the table are the summarized impulse response functions derived from a set of 5 VAR specifications. The second column summarize s the impulse response functions of the interest rate after an expansionary monetary shock. The third and fourth columns display the summarized reactions of the output and the price levels.

Table 6. Liquidity Effect with R-Rules

\begin{tabular}{|l|l|l|l|}
\hline & Liquidity Effect & Response of GDP & Response of CPI \\
\hline Cameroon & $\begin{array}{l}\text { Yes but only for the last 2 VAR } \\
\text { specifications }\end{array}$ & As Expected & Inflation Puzzles \\
\hline Central AF REP & No & Not as Expected & Not as Expected \\
\hline Chad & No & Quite as Expected & Not as Expected \\
\hline Congo & Presence of Puzzles & Presence of Puzzles & Not as Expected \\
\hline Equatorial Guinea & As Expected & Not as Expected & As Expected \\
\hline Gabon & Yes but just slight & Not really as Expected & Not as Expected \\
\hline CEMAC & No & Presence of Puzzles & Not as Expected \\
\hline
\end{tabular}

Note: The entries in the table are the summarized impulse response functions derived from a set of 5 VAR specifications. The second column summarize s the impulse response functions of the monetary aggregate after an innovation on the interest rate. The third and fourth columns display the summarized reactions of the output and the price levels.

Table 7. Loanable Effect

\begin{tabular}{|l|l|l|l|}
\hline & Loanable Effect & Response of GDP & Response of CPI \\
\hline Cameroon & Yes & Not as Expected & Price Puzzles \\
\hline Central AF REP & NO & Not as Expected & As Expected \\
\hline Chad & Yes & Presence of Puzzles & As Expected \\
\hline Congo & No & As Expected & As Expected \\
\hline Equatorial Guinea & Yes & Presence of Puzzles & Presence of Puzzles \\
\hline Gabon & Yes & Presence of Puzzles & As Expected \\
\hline CEMAC & Yes & As Expected & As Expected \\
\hline
\end{tabular}

Note: The entries in the table are the summarized impulse response functions derived from a set of 5 VAR specifications. The second column summarize $\mathrm{s}$ the impulse response functions of the interest rate after a credit expansion. The third and fourth columns display the summarized reactions of the output and the price levels. 